\title{
STRATEGI PEMBERDAYAAN USAHA MIKRO, KECIL DAN MENENGAH (UMKM) DI KOTA KEDIRI
}

\author{
Strategy For Empowerment Of Micro, Small And Medium Enterprises (UMKM) In Kediri City
}

\author{
Silvirgin Latisia ${ }^{1}$ \\ ${ }^{1}$ Magister Ilmu Administrasi Universitas Kadiri
}

\begin{abstract}
Abstrak
Penelitian ini bertujuan untuk mendeskripsikan strategi DinKop UMKM dalam memberdayakan Usaha Mikro, Kecil, dan Menengah (UMKM) yang berfokus pada sektor perdagangan. Hal ini dilatarbelakangi oleh munculnya pasar-pasar modern yang merambah ke pelosok-pelosok daerah, sihingga secara tidak langsung mematikan pasar-pasar traditional. Sehingga hal ini berdampak pada pelaku UMKM yang menghasilkan product dengan kualitas tidak dapat besaing dengan produk pasar modern. Dalam hal ini mekanisme pemasaran yang menjadi salah satu tolak ukur dalam pengembangan UMKM. Selain itu pemberdayaan yang dilakukan oleh DinKop UMKM harus dimaksimalkan guna meningkatkan kapasitas sumber daya manusia agar dapat menghasilkan produk yang inovatif. Dalam memberdayakan usaha mikro, kecil, dan menengah diperlukan tiga fase inisial, fase partisiptoris, dan fase emansipatoris. Metode penelitian yang digunakan adalah diskriptif kualitatif. Hasil penelitian ini menunjukka bahwa strategi pemberdayaan Dinkop UMKM dalam memberdayakam usaha mikro,kecil, dan menengah kurang berjalan optimal. Pemberdayaan yang dilakukan oleh pemerintah pada fase inisial cukup berperan dengan memberikan pelatihan dan penyuluhan. Selanjutnya pada fase partisipatoris masyarakat dan pemerintah sudah berkolaborasi dalam mengembangkan UMKM. Sementara pada fase selanjutnya pemerintah masih terkendala pada penyediaan sarana dan presarana dalam pengembangan UMKM.
\end{abstract}

Kata kunci: Strategi Pemberdayaan; UMKM; pengembangan ekonomi

\section{Abstract}

This study aimed to describe the strategy DinKop UMKM in empowering Micro, Small, and Medium Enterprises ( UMKM) which focused on the trade sector. In this case, the marketing mechanism which became one of the benchmarks in the development of UMKM. Moreover, empowerment conducted by DinKop UMKM should be maximized to increase the capacity of human resources in order to produce innovative products. In empowering micro, small, and medium-needed three phases which initials, participators phase, and phase emancipatory. This research method is descriptive qualitative. Data collection instruments are interviews and observations on location and also based on documents/ records/reports and legislation relating to the matter being investigated. The focus of this research is based on the initial phase, the phase of the participatory, emancipatory phase. These results indicate that the empowerment strategy DinKop UMKM in empowering Small, Mikro, and Medium Enterprises is not running optimally. Empowerment undertaken by the government in the initial phase is quite a role in providing training and counseling. The next step of participatory society and government have collaborated in developing UMKM. While the government is still constrained emancipatory phase of the provision of facilities and infrastructure in the development of UMKM.

Keywords: Empowerment Strategy; UMKM; Economy Development 


\section{A. PENDAHULUAN}

Era Masyarakat Ekonomi ASEAN (MEA) pada 2015 membawa suatu peluang sekaligus tantangan bagi ekonomi Indonesia. Dengan diberlakukannya MEA pada akhir 2015, negara anggota ASEAN akan mengalami aliran bebas barang, jasa, investasi, dan tenaga kerja terdidik dari dan ke masing-masing negara. MEA merupakan sebuah kesempatan sekaligus beban yang harus dipikul oleh pelaku UMKM dalam negeri. Melalui MEA akan terjadi integrasi yang berupa "free trade area" atau dikenal dengan area perdagangan bebas, penghilangan tarif perdagangan antar negara ASEAN, serta pasar tenaga kerja dan pasar modal yang bebas, yang akan sangat berpengaruh pada pertumbuhan dan pembangunan ekonomi tiap negara.

Data Kementerian Koperasi dan UMKM menunjukkan pada 2012, total UMKM mencapai 56,5 juta unit atau setara dengan $99,9 \%$ dari total unit usaha di Indonesia. Dari total unit usaha UMKM tersebut, apabila dirinci maka mayoritas UMKM didominasi oleh usaha mikro sebanyak 55,8 juta unit atau 98,7\%. Selanjutnya diikuti oleh usaha kecil 629.418 unit $(1,11 \%)$ dan usaha menengah 48.997 $(0,99 \%)$. Itu artinya $99.9 \%$ unit usaha di Indonesia yang merupakan UMKM harus bersiap berada di garis depan pembangunan ekonomi Indonesia.

Namun yang masih menjadi momok adalah kesiapan produk-produk UMKM menjadi produk komoditi ekspor. Meski menyumbang $57,48 \%$ produk domestik bruto, namun, kinerja ekspor produk UMKM masih kalah jauh dibanding usahausaha besar. Produk-produk UMKM hanya mampu berkontribusi terhadap ekspor sebesar $14,06 \%$. Inilah beban tugas yang harus diemban pemerintah.

Dinas Koperasi, Usaha Mikro, Kecil dan Menengah sebagai salah satu perangkat daerah di lingkungan Pemerintah Kota Kediri, berkewajiban mengantarkan dan menyiapkan masyarakat koperasi dan UMKM Kota Kediri menghadapi tantangan yang semakin kompleks. Untuk memperoleh tujuan akhir yang optimal, maka disusunlah strategis yang memuat visi, misi, tujuan, sasaran, strategi, kebijakan dan kemudian dituangkan ke dalam beberapa program serta diaplikasikan dalam bentuk kegiatan sebagaimana diamanatkan Undang-undang Nomor 32 tahun 2004 tentang Pemerintahan daerah.dimana Dinas Koperasi, Usaha Mikro, Kecil dan Menengah memiliki tugas pokok sebagai lembaga penyusun dan pelaksana kebijakan daerah di bidang pemberdayaan koperasi dan usaha mikro, kecil dan menengah termasuk penyelenggaraan Pelayanan seperti melaksanakan bimbingan, pendampingan dan pengelolaan asilitasi pembiayaan dan simpan pinjam bagi koperasi, UMKM. Pembinaan pelatihan teknis untuk pengusaha mikro, kecil dan menengah, ketrampilan permodalan/penenaman modal bagi koperasi, industry kecil, UMKM, pengawasan serta pengendalian simpan pinjam bagi pengusaha mikro, kecil dan menengah

Menyadari peran koperasi dan UMKM yang begitu penting, bukan hanya komitmen yang kuat, namun diperlukan juga perencanaan yang matang untuk dapat mengembangkan energi potensial koperasi dan UMKM. upaya pemberdayaan Koperasi UMKM bukanlah suatu komitmen kebijakan jangka pendek, tetapi merupakan proses politik jangka panjang. Untuk itu diperlukan sebuah rencana strategis jangka panjang yang berkelanjutan. Pembangunan koperasi UMKM yang sepotong-sepotong tidak akan menghasilkan pembangunan koperasi UMKM yang berdaya saing.

Keberadaan usaha kecil merupakan konsekuensi logis upaya transformasi sosial, ekonomi dan politik dari sistem perekonomian yang mengandalkan pada sektor pertanian menuju basis ekonomi non pertanian. Sesuai dengan komitmen pemerintah bahwa untuk pengembangan usaha kecil di pedesaan merupakan langkah yang kongkrit guna menjawab masalah ketenagakerjaan di pedasaan.

.Komitmen tersebut diperkuat oleh pernyataan Saleh (2006) bahwa untuk merangsang pengembangan pekerjaan bukan pertanian di daerah pedesaan adalah pengembangan industrialisasi pedesaan, 
yaitu usaha kecil.

Untuk melakukan upaya tersebut agar UMKM Kota Kediri mampu bersaing dan berperan sebagai badan usaha atau pengusaha yang tangguh dan mandiri, diperlukan modal yang kuat, oleh karena itu Pemerintah Kota Kediri membuka akses terhadap pengembangan kekuatan modal sesuai dengan Peraturan Daerah Kota Kediri Nomor 19 tahun 2007 tentang Modal Penyertaan Melalui Program Pemberdayaan Kepada Koperasi, Usaha Mikro, Kecil dan Menengah. Modal penyertaan adalah sejumlah uang atau barang modal yang ditanamkan oleh Pemodal untuk menambah dan memperkuat Koperasi, usaha mikro, kecil dan menengah dalam meningkatkan kegiatan usahanya. Sedangkan Program Pemberdayaan kepada Koperasi, Usaha Micro, Kecil dan Menengah adalah rangkaian kegiatan Pemerintah Kota Kediri dalam rangka percepatan pemulihan ekonomi paska krisis dalam bentuk penyertaan modal Pemerintah Daerah. Sasaran dari Program tersebut adalah :

a. Tersalurnya dana modal penyertaan Pemerintah Kota Kediri kepada koperasi dan UMKM di Kota Kediri

b. Terwujudnya peningkatan Penerimaan Asli Daerah (PAD) dari Masyarakat Gerakan Koperasi dan pelaku UMKM sebagai bentuk partisipasi secara langsung dalam proses pembangunan di Kota Kediri

c. Terwujudnya dana perguliran baru kepada koperasi dan UMKM dalam rangka peningkatan dan pengembangan usaha

d. Terlaksananya program beserta perawatan program dalam rangka memperkuat permodalan bagi koperasi dan UMKM di Kota Kediri dengan prinsip Tri Sukses yaitu : Sukses Penyaluran, Sukses pemanfaatan, Sukses Pengembalian dana sehingga terwujud peningkatan dan pengembangan usaha ekonomi produktif.

- Sukses penyaluran adalah pemberian modal dari Pemerintah Kota Kediri dapat tersalurkan kepada penerima modal (Koperasi atau UMKM) yang memerlukan.

- Sukses pemanfaatan adalah pemberian modal kepada Koperasi atau UMKM dapat dimanfaatkan penerima modal untuk mengembangkan usaha mereka.

- Sukses pengembalian dana adalah penerima modal sedapat mungkin mengembalikan pemberian modal yang diterimanya dalam tenggang waktu sesuai perjanjian kepada Pemerintah Kota Kediri.

Namun dalam pelaksanaan Program Pemerintah Kota Kediri pasti ada beberapa faktor - faktor yang dapat menghambat terlaksananya program tersebut,faktor faktor tersebut adalah faktor Internal dan Ekternal. Faktor internalnya adalah Sumber daya yang dimiliki, Pemasaran, dan Produksinya. Sedangkan faktor eksternalnya adalah pertumbuhan ekonomi, sosial budaya, jumlah penduduk, dan perkembangan teknologi serta kondisi kelompok pesaing ataupun kelompok pendukungnya.

Sedangkan selain Mengetahui faktorfaktor tersebut kemampuan pengusaha dalam menentukan strategi juga sangat mempengaruhi Pemberdayaan UMKM Kota Kediri, sehingga usaha tersebut diharapkan dapat terus diberdayakan dan semakin berkembang yaitu dengan memanfaatkan setiap kondisi lingkungan dan peluang yang ada. Dengan melihat kenyataan ini maka dipandang perlu untuk mengadakan penelitian tentang strategi pemberdayaan usaha mikro kecil dan menengah. Rumusan masalah penelitian ini yakni, strategi apa yang harus dilakukan dan sesuai untuk menghadapi kendala Pemberdayaan UMKM di Kota Kediri.

\section{B. LANDASAN TEORITIS}

\subsection{Usaha Mikro Kecil Dan Menengah (UMKM)}

UMKM merupakan kegiatan ekonomi yang mendominasi lebih dari 95\% struktur perekonomian Indonesia. Sektor ini memiliki peran yang strategis baik secara ekonomi maupun sosial politis. Fungsi 
ekonomi sektor ini antara lain menyediakan barang dan jasa bagi konsumen berdaya beli rendah sampai sedang, menyumbang lebih dari sepertiga pertumbuhan ekonomi serta kontribusi dalam perolehan devisa negara. Secara sosial politis, fungsi sektor ini juga sangat penting terutama dalam penyerapan tenaga kerja serta upaya pengentasan kemiskinan (BPIK,2004). Pemberdayaan dan pengembangan usaha kecil merupakan kebutuhan yang mendasar bagi Indonesia yang menganut sistem perekonomian yang khas yakni Ekonomi Kerakyatan.

Di Indonesia kesulitan untuk mendefinisikan usaha kecil sangat terlihat dari keragaman batasan tentang usaha kecil, dimana setiap instansi secara sektoral membangun batasan dan definisi sendiri. Batasan dan definisi dibangun untuk kepentingan administrasi dan pengembangan program kerja sektoral masing-masing. Setiap instansi tidak mempunyai kesepakatan tentang hal ini, ketidak kesepakatan tersebut terutama terletak pada batas maksimal dari usaha kecil. Batasan tersebut menunjukkan keberbihakan dan paradigma yang dianut, sehingga seringkali batasan menjadi tidak jelas, saling berbenturan dan overlapping.

\subsection{Manajemen Strategi}

Strategi dalam konteks awalnya diartikan sebagai generalship atau suatu yang dikerjakan oleh para jendral dalam membuat rencana untuk menaklukkan musuh dan memenangkan orang ( Setiawan, 2008 ). Tidaklah mengherankan jika pada awalnya strategi ini memang populer dan digunakan secara luas dalam dunia militer. Porter ( 2000 ) mengatakan bahwa strategi adalah merumuskan apa yang akan dilakukan perusahaan dalam mencapai tujuan, tetapi karena keadaan di dalam dan di luar perusahaan yang membatasi, maka perusahaan perlu mengadakan manuver dan manuver tersebut dinamakan strategi. Dari pengertian tersebut maka strategi ditujukan untuk mengantisipasi berbagai perubahan, baik positif maupun negatif yang dapat mempengaruhi industri guna menentukan posisi dimasa depan.

\section{Lebih jauh Siagian ( 2006 )} memberikan definisi bahwa manajemen strategi adalah serangkaian keputusan dan tindakan mendasar yang dibuat oleh manajemen puncak dan diimplementasikan oleh seluruh jajaran suatu organisasi dalam rangka pencapaian tujuan organisasi tersebut. Apabila dihubungkan dengan pendapat Wahyudi (2006). Manajemen Strategi adalah suatu seni dan ilmu dari pembuatan ( formulating), penerapan ( implementing ) dan evaluasi ( evaluatif ). Keputusan - keputusan strategis antar fungsi - fungsi yang memungkinkan sebuah organisasi mencapai tujuan - tujuan masa datang. Jadi manajemen strategis merupakan usaha manajerial menumbuh kembangkan kekuatan perusahaan untuk mengekploitasi peluang yang muncul guna mencapai tujuan yang telah ditetapkan sesuai dengan misi yang telah ditentukan ( Suwarsono, 2004 )

Pengertian tersebut mengandung implikasi bahwa perusahaan atau industri berusaha mengurangi kelemahan serta effect negatif dari pada hambatan / ancaman . Atau lebih tegas lagi strategi selalu "memberikan sebuah keuntungan" sehingga jika proses manajemen yang dilakukan oleh perusahaan gagal untuk menciptakan keuntungan bagi perusahaan / organisasi maka proses manajemen tersebut tidak dapat disebut manajemen strategi. Dengan menggunakan manajemen strategi sebagai suatu kerangka kerja ( frame work ) untuk menyelesaikan setiap masalah strategi didalam perusahaan terutama yang berkaitan dengan persaingan, maka para manajer / pimpinan diajak untuk berfikir lebih kreatif atau berfikir secara strategis.

Ada beberapa manfaat yang bisa diperoleh organisasi jika mereka menerapkan manajemen strategi : ( Wahyudi, 2006 )

- Memberikan arah jangka panjang yang akan dituju.

- Membantu organisasi beradaptasi pada perubahan - perubahan yang terjadi.

- Mengidentifikasi keunggulan komparatif suatu organisasi dalam lingkungan. 
- Mempertinggi perusahaan munculnya masalah.

untuk

kemampuan mencegah

- Aktivitas yang tumpang tindih akan dikurangi.

- Memberikan arah dan tujuan perusahaan dengan jelas.

Dengan melihat beberapa manfaat diatas pimpinan perusahaan dapat mengantisipasi perubahan dan menyiapkan petunjuk serta pengendali yang memungkinkan perusahaan untuk membuat cara baru dari adanya peluang yang tersedia dalam lingkungan. Disamping itu juga dapat mengurangi resiko, karena telah mengantisipasi lebih dahulu ke depan.

\section{METODE PENELITIAN}

Dalam penelitian ini melibatkan berbagai elemen terkait, mulai dari aparatur pemerintah daerah, petugas di dinas Koperasi UMKM Kota Kediri,dan masyarakat. Asumsi yang dibangun dari masing-masing elemen adalah untuk membentuk gambaran yang aktual, faktual, komprehensif, dan objektif.

Penelitian atas subjek untuk mendapatkan data akan dilakukan dalam kurun waktu tertentu sesuai alokasi waktu yang direncanakan. Data itu adalah data primer sebagai pendukungnya, diperoleh dari Dinas Koperasi dan UMKM Kota Kediri yang berkaitan dengan program pemberdayaan Koprasi dan UMKM dan Dinas Pendapatan, Pengelolaan Keuangan dan Aset (DPPKA) Kota Kediri terkait dengan Pendapatan Asli Daerah. Data sekunder diperoleh dari pengusaha UMKM . Hasilnya akan digunakan untuk bahan analisis dan kajian mendalam sehingga memberikan manfaat bagi Pemerintah Daerah dan khalayak yang memiliki urgensi atas penelitian ini.

\section{PEMBAHASAN}

\subsection{Startegi Pemerintah Kota Kediri dalam Pemberdayaan UMKM}

Keberadaan usaha kecil di pedesaan dalam suatu sistem sangat dipengaruhi oleh lingkungan disekitarnya, baik meyangkut lingkungan internal maupun lingkungan ekternal. Pengaruh yang diberikan oleh lingkungan tersebut berdampak pada kebijaksanaan serta strategi yang akan diambil. Terjadinya perubahan-perubahan pada lingkungan internal akan berpengaruh terhadap kekuatan maupun kelemahan, begitu juga dengan adanya perubahan lingkungan ekternal akan memberikan pengaruh potensial dan mendasar bagi terciptanya peluang maupun ancaman dimasa sekarang maupun masa yang akan adatang.

Dengan berpijak pada keadaan diatas, maka diharapkan usaha Mikro, Kecil dan Mennengah di Kota Kediri mampu untuk mengantisipasi terjadinya perubahanperubahan melalui pengambilan keputusan strategis.

Ada beberapa alternatif strategi yang bisa diterapkan dalam suatu asaha, tentunya penerapan strategi yang tepat akan membawa kemajuan yang berarti bagi usaha itu. Strategi-sytrategi yang bisa diterapkan dalam suatu usaha antara lain :

\subsection{Kebijakan Pemerintah Dalam Bantuan Modal}

Perkembanagan Usaha Mikro, Kecil dan Menengah (UMKM) di Kota Kediri tidak terlepas dari dukungan perbankan dalam penyaluran kredit kepada UMKM. Setiap tahun kredit kepada UMKM mengalami pertumbuhan dan secara umum pertumbuhannya lebih tinggi dibanding total kredit perbankan. Keberhasilan Usaha Mikro, Kecil dan Menengah di Kota Kediri juga tidak terlepas dari dukungan dan peran pemerintah Kota Kediri dalam mendorong penyaluran kredit kepada UMKM. Berbagai skim kredit/ pembiayaan UMKM diluncurkan oleh Pemerintah dikaitkan dengan tugas dan program pembangunan ekonomi pada sektor-sektor usaha tertentu misalnya ketahanan pangan, peternakan dan perkebunan. Peran Pemerintah dalam skimskim kredit UMKM ini adalah pada sisi penyediaan dana APBD untuk subsidi bunga skim kredit dimaksud.

Sabirin (2001) menjelaskan bahwa untuk memberdayakan masyarakat 
golongan ekonomi lemah atau sektor usaha kecil adalah dengan menyediakan sumber pembiayaan usaha yang terjangkau. Lembaga keuangan mikro merupakan institusi yang menyediakan jasa-jasa keuangan penduduk yang berpendapatan rendah dan masuk dalam kelompok miskin . Lembaga keuangan mikro ini bersifat spesifik karena mempertemukan permintaan dana penduduk miskin atas ketersediaan dana. Bagi lembaga keuangan formal perbankan, penduduk miskin akan tidak dapat terlayani karena kesuksesan pemberdayaan UMKM akan terwujud bila semua stakeholder berperan secara bersamasama sesuai peran masing-masing. Baik regulator termasuk Pemerintah Daerah, para pelaku UMKM dan dunia perbankan yang dapat bekerja sesuai dengan tugas dan fungsinya, maka keberhasilan dan kemajuan UMKM akan cepat terlaksana. Sehingga pada akhirnya peningkatan penerimaan pajak dari sisi penggalian wajib pajak baru maupun nilai pajaknya akan terus meningkat.

Pemerintah daerah Kota Kediri sebagai regulator, pada dasarnya telah mengeluarkan program atau skim yang telah disediakan untuk pemberdayaan UMKM. Program inn hendaknya terus dioptimalisasi. Program tersebut adalah Program Nasional Pemberdayaan Masyarakat mandiri (PNPM). Demikian juga Masalah permodalan merupakan masalah klasik yang dihadapi oleh para pelaku UMKM, tidak terkecuali bagi pelaku UMKM di daerah Kota Kediri. Untuk itu Pemerintah Kota Kediri melakukan upaya-upaya strategis untuk meningkatkan aksesibilitas permodalan bagi pelaku UMKM. Program yang dikeluarkan oleh Pemerintah Kota Kediri dalam bentuk kemitraan sesuai dengan Peraturan Daerah Kota Kediri Nomor 19 tahun 2007 tentang Modal Penyertaan melalui Program pemberdayaan kepada Koperasi, Usaha Mikro, Kecil dan Menengah.

Adapun Program-program yang dilakukan untuk memperkuat struktur permodalan adalah melalui bantuan pinjaman dana lunak dan bantuan dana hibah serta temu bisnis untuk menggalang kemitraan dengan pihak swasta. Salah satu kegiatan yang mendukung aksesibilitas permodalan bagi UMKM adalah pemberian bantuan Dana Bergulir.Program dijalankan oleh satu SKPD yaitu Dinas Koperasi dan UMKMdan DPPKAD (Dinas Pendapatan, Pengelolaan Keuangan dan Aset Daerah). Alokasi Anggaran yang tersedia adalah Rp. 1.000.000.000,00 (satumilyar rupiah). Rincian modal penyertaan Pemerintah Daerah dapat dilihat pada tabel 5.2 .1 berikut :

Bantuan dana dilakukan dengan sistem pinjaman dana bergulir dengan bunga pinjaman sebesar $4 \%$ per tahun atau hanya $0,5 \%$ per bulan dalam jangka waktu 3 tahun. Proses pengajuan pinjaman serta verifikasi dilakukan oleh Dinas Koperasi dan UMKM , sedangkan pencairan pinjaman dilakukan oleh DPPKAD. Bantuan pinjaman ini diberikan kepada para pelaku UKM modalnya masih kecil dan mempunyai minat serta membutuhkan pinjaman modal tersebut.

Adapun syarat untuk mendapatkan bantuan dana bergulir adalah

\section{Syarat Penyertaan Modal Bergulir Perorangan (Pelaku UMKM)}

1. Mengajukan permohonan (proposal)kepada kepala Dinas Koperasidan UMKM Kota Kediri (rangkap2)

2. Surat permohonan proposal dilampiri

a. FC. Perijinan usaha yang dimiliki seperti SIUP, TDP, NPWP, Ho(bagi usaha yang memiliki dampak terhadap lingkungan) dan perijinan lainnya

b. FC KTP, KK pemohon yang masih berlaku.

c. FC Surat nikah pemohon (suami).

d. Pas Fotosuami istri $4 \times 6$ a 2 Lembar

e. FC. Sertifikat/BPKB

(dokumenjaminan) untuk BPKB Mobil berlaku 10 tahun keberlakuannya dan untuk BPKB Motor 5 tahun

f. Keberlakuannya di Surat pernyataan sanggup menyerahkan jaminan bermaterai lampiri Foto Copy Jaminan (untuk jaminan sertifikat disertai PBB dan foto jaminan) 
g. SyaratKeterangan Taksiran Harga dari Kelurahan (apabila jaminan berupa sertifikat)

h. FC. Pajak Bumi dan Bangunan dan sertifikatjaminan.

i. Surat Pernyataan persetujuansuami istri.

j. Denah dan Foto Kegiatan usaha serta profil perusahaan Lokasi

k. Rencana kebutuhan dana

1. FC. KTP KK, Surat Nikah pemilik jaminan (apabila jaminan bukan milik koperasi)

m. Surat Pernyataan Sanggup disurvey

n. FotoLokasi dan barang yang dijaminkan

3. Batas Usia maksimal Peminjam'Pengakses adalah 60 tahun pada saat realisasidan Ber-KTP Kota Kediri

\section{Syarat Penyertaan Modal Untuk Koperasi}

1. Mengajukan permohonan (proposal) kepada kepala Dinas Koperasi dan UMKM Kota Kediri

2. Surat Permohonan Proposal dilampiri

a. NaskahRATdalam2 (dua) tahun terakhir

b. FC. Akta Pendirian dan Perizinan lainnya

c. FC. KTPpengurus dan pengawas lengkap

d. Pas Foto Pengurus dan Pengawas lengkap 4x6 (@2 Lembar)

e. FC. Sertifikat Penilaian Kesehatan.

f. Susunan Pengurus dan Pengawas dilegalisir Kepala Dinas Koperasi dan UMKM Kota Kediri.

g. Berita Acara Rapat Anggota tentang pengajuan dana bergulir dan kuasa kepada pengurus

h. FC. Sertifikat/BPKB (dokumen jaminan) untuk BPKB Mobil (berlaku 10 Tahun)

i. Surat pernyataan sanggup menyerahkan jaminan bermaterai di lampiri Foto Copy Jaminan (untuk jaminan sertifikat disertai PBB dan foto jaminan).

j. Syarat Keterangan Taksiran Harga dari Kelurahan (apabila jaminan berupa sertifikat) k. FC. Pajak Bumi dan Bangunan dan sertifikat jaminan.

1. FC. KTP KK Surat Nikah pemilik jaminan (apabila jaminan bukan milik koperasi)

m. Surat Pernyataan Sanggupdisurvey

n. Surat Pernyataan Asset koperasi sebagai jaminan pinjaman (apabilajaminan tidak mencukupi)

o. Denah Lokasi dan Foto Kegiatan usaha Koperasi lidentitas Koperasi.

p. Rencana Kebutuhan Dana.

q. Foto Lokasi dan barang yang dijaminkan.

Selain bantuan dari pihak Pemerintah Daerah diharapkan Bank Indonesia bekerjasama untuk lebih berperan aktif melakukan pembinaan dan berbagai aktifitas untuk pemberdayaan UMKM dalam bentuk program Konsultan Keuangan Mitra Bank. Program ini dimaksudkan antara lain sebagai pendampingan manajerial baik dibidang keuangan, pemasaran, kapasitas pengelolaan serta administrasi UMKM. Hal senada juga dilakukan oleh beberapa Pemerintah Daerah berupa program ekonomi kerakyatan pemda serta keunggulan komparatif daerah. Salah satu hal terpenting lagi adalah program sosialisasi berbagai program agar programprogram pemberdayaan UMKM dapat dengan mudah diakses.

\subsection{Perluasan Akses Informasi Jaringan Pemasaran bagi UMKM}

Dalam menghadapi mekanisme pasar yang makin terbuka dan kompetitif, penguasaan pasar merupakan prasarat untuk meningkatkan daya saing UMKM. Agar dapat menguasai pasar, maka UMKM perlu mendapatkan informasi dengan mudah dan cepat, baik informasi mengenai pasar produksi maupun pasar faktor produksi. Informasi tentang pasar produksi sangat diperlukan untuk memperluas jaringan pemasaran produk yang dihasilkan oleh UMKM. Informasi pasar produksi atau pasar komoditas yang diperlukan misalnya :

1) Jenis barang atau produk apa yang paling dibutuhkan oleh konsumen di daerah tertentu 
2) Bagaimana daya beli masyarakat terhadap produk tersebut,

3) Berapa harga pasar yang berlaku

4) Selera konsumen pada pasar lokal regional, maupun internasional

Degan demikian, UMKM dapat mengantisipasi berbagai kondisi pasar sehingga dalam menjalankan usahanya akan lebih inovatif. Sedangkan informasi pasar faktor produksi juga diperlukan terutama untuk mengetahui :

1) Sumber bahan baku yang dibutuhkan

2) Harga bahan baku yang ingin dibeli

3) Dimana dan bagaiman memperoleh modal usaha

4) Dimana mendapatkan tenaga kerja yang profesional

5) Tingkat upah atau gaji yang layak untuk pekerja ,

6) Dimana dapat memperoleh alat-alat atau mesin yang dipelukan (Effendi Ishak, 2005)

Informasi pasar yang lengkap dan akurat dapat dimanfaatkan oleh UMKM di Kota Kediri untuk membuat perencanaan usahanya secara tepat,misalnya :

1) Membuat desain produk yang disukai konsumen

2) Menentukan harga yang bersaing di pasar

3) Mengetahui pasar yang akan dituju, dan banyak manfaat lainnya.

Oleh karena itu peran pemerintah daerah sangat diperlukan dalam mendorong keberhasilan UMKM dalam memperoleh akses untuk memperluas jaringan pemasarannya.

Selain memiliki kemudahan dan kecepatan dalam memperoleh informasi pasar, UMKM juga perlu memiliki kemudahan dan kecepatan dalam mengkomunikasikan atau mempromosikan usahanya kepada konsumen secara luas baik di dalam maupun diluar negeri. Selama ini promosi UMKM di Kota Kediri lebih banyak dilakukan melalui pameran-pameran bersama dalam waktu dan tempat yang terbatas, sehingga hubungan maupun transaksi dengan konsumen kurang bisa dijamin keberlangsungannya. Hal itu dapat disebabkan oleh jarak yang jauh atau kendala intensitas komunikasi yang kurang. Padahal faktor komunikasi dalam menjalankan bisnis adalah sangat penting, karena dengan komunikasi akan membuat ikatan emosional yang kuat dengan pelanggan yang sudah ada, juga memungkinkan datangnya pelanggan baru.

\subsection{Promosi Produk Unggulan}

Mengatasi adanya keterbatasan pemasaran pelaku UMKM di Kota Kediri, serta persaingan yang tidak sehat dari para pelaku UMKM, peningkatan aksesibilitas pada pasar yang telah dilakukan pemerintah melalui pameran dan promosi produkproduk unggulan daerah, temu bisnis, pembuatan leaflet dan pembinaan pengemasan. Upaya promosi dilakukan dengan mengikuti pameran di dalam daerah, seperti pada saat hari Koperasi, Hari jadi Kota Kediri ataupun pameran di beberapa event Pemerintah Kota Kediri pada saat ada tamu dari luar daerah atau dari luar negeri. Promosi produk unggulan juga bisa dengan mengikuti pameran di luar daerah yang potensial pada moment-moment tertentu, seperti pada Event seperti pameran Dekranasda yang biasa dilaksanakan di Kota- kota besar setiap tahunnya, Event Jakarta Fashion Week, Gelar kerajinan nasional daerah dan produk industri kreatif nusantarayang dapat menjadi tolok ukur penting bagi kemajuan UMKM di Kota Kediri, kegiatan ini sangat bermanfaat bagi pelaku UMKM karena ada ratusan stan yang diperuntukan pelaku UMKM tanpa dikenakan biaya apapun alias gratis guna mengenalkan produk-produk unggulannya untuk dipamerkan/dipasarkan. Kegiatan ini bertujuan untuk mempromosikan produk unggulan daerah, menjaring konsumen dan menggalang kontak dagang serta mengikuti perkembangan pasar. Pada kegiatan ini sasaran peserta yang diikutkan dalam kegiatan ini lebih diperluas, tidak hanya yang sudah mengikuti kegiatan pameran secara aktif saja, tetapi juga kepada para pelaku UMKM yang belum berdaya dan belum mengikuti pameran lebih didorong dan dimotivasi untuk mengikutinya. 
4.5. Strategi Meningkatkan Sumber Daya Manusia Untuk . Menghadapi Pasar Bebas Asean

\subsubsection{Penguatan lembaga pendamping melalui Peningkatan Capacity Building}

Setyobudi (2017) menyebutkan bahwa Bank Indonesia lebih fokus pada penguatan lembaga pendamping UMKM melalui peningkatan capacity building dalam bentuk pelatihan dan kegiatan penelitian yang menunjang pemberian kredit kepada UMKM. Beberapa upaya yang dilakukan antara lain :

a. Pelatihan- pelatihan kepada lembaga pendamping UMKM, dalam rangka meningkatkan kemampuan kredit UMKM.

b. Pendirian pusat Pengembangan Pendamping UKM (P3UKM), sebagai pilot projet. P3UKM antara lain bertugas melakukan pelatihan akreditasi pendamping UKM

c. Pengembangan Sistem Informasi Terpadu Pengembangan Usaha Kecil (SIPUK) sebagai sarana untuk lebih menyebarluaskan secara cepat hasil-hasil penelitian dan berbagai informasi lainnya. SIPUK terdiri dari Sistem Informasi Baseline Economic Survey (SIB), Sistem Informasi Agroindustri Berorientasi Ekspor (SIABE), Sistem Informasi Pola Pembiayaan / lending model Usaha Kecil (SILMUK), Sistem Penunjang Keputusan Untuk Investasi (SPKUI) dan Sistem Informasi Prosedur Memperoleh Kredit (SIPMK). SIPUK ini dapat diakses melalui website Bank Indonesia.

d. Berbagai penelitian dalam rangka memberikan informasi untuk mendukung pengembangan UMKM. Kegiatan penelitian terutama diarahkan untuk mendukung penetapan arah kebijakan Bank Indonesia dalam rangka pemberian bantuan teknis dan juga dalam rangka penyediaan informasi yang berguna dalam rangka pengembangan UMKM. Penelitian tersebut disesuaikan dengan kebutuhan pengembangan UMKM serta untuk menggali potensi sektor UMKM di tiap-tiap daerah di Indonesia. Dalam upaya meningkatkan peran UMKM untuk mendorong pertumbuhan ekonomi. Bank Indonesia melakukan kajian identifikasi peraturan pusat dan daerah dalam rangka pengembangan UMKM serta kajian dan implementasi pilot project klaster pengembangan UMKM.

Sesuai dengan pernyataan diatas untuk strategi penguatan lembaga pendamping UMKM melalui peningkatan capacity building dalam bentuk pelatihan. Pemerintah Kota Kediri harus lebih intensif dalam Penyelenggaraan pelatihan kewirausahaan

Untuk menciptakan wirausaha baru (pelaku UMKM), maupun pengembangan dan pemberdayaannya salah satunya lewat kegiatan pelatihan kewirausahaan. Di Kota Kediri sudah pernah melaksanakan kegiatan Pelatihan kewirausahaan bagi pelaku UMKM antara lain:

a. Pelatihan membatik khas Kota Kediri, dengan mengirimkan 6 orang pelaku UMKM di Sentra Batik desa dermo dan di fasilitasi oleh Disperindag.

b. Pelatihan menjahit dan border dengan mendatangkan narasumber dari SKPD terkait untuk memberi pelatihan usaha tentang menjahit dan bordir bagi pelaku UMKM sebanyak 25 orang di tiap Kecamatan.

c. Pelatihan ternak ikan Lele dengan mendatangan narasumber Dinas Perikanan dan Kelautan Kota Kediri dan Provinsi Jawa Timur bagi pelaku usaha ternak ikan lele.

Diharapkan tiap Pelatihan dilakukan secara berkala, karena pelatihan-pelatihan dan seminar bisa menambah ilmu dan ketrampilan bagi pelaku UMKM di Kota Kediri.

\subsubsection{Pengembangan Sumber Daya Manusia pada UMKM melalui IT (Information Technologi)}

Teknologi informasi merupakan bentuk teknologi yang digunakan untuk menciptakan, menyimpan, mengubah, dan menggunakan informasi dalam segala bentuknya. Melalui pemanfaatan teknologi ini, perusahaan mikro, kecil, maupun menengah dapat memasuki pasar global. Perusahaan yang awalnya kecil seperti toko buku Amazon, portal Yahoo, dan perusahaan lelang Ebay, ketinganya saat ini 
menjadi perusahaan raksasa hanya dalam waktu singkat karena memanfaatkan teknologi informasi dalam pengembangan usahanya.

Pemanfaatan teknologi informasi dalam menjalankan bisnis atau sering dikenal dengan istilah e-commerce bagi perusahaan kecil dapat memberikan fleksibilitas dalam produksi, memungkinkan pengiriman ke pelanggan secara lebih cepat untuk produk perangkat lunak, mengirimkan dan menerima penawaran secara cepat dan hemat, serta mendukung transaksi cepat tanpa kertas. Pemanfaatan internet memungkinkan UMKM melakukan pemasaran dengan tujuan pasar global, sehingga peluang menembus ekspor terbuka luas.

Biaya transaksi (Transaction Cost), merupakan biaya-biaya yang timbul dari proseskegiatan bisnis. Biaya ini mencakup biaya komunikasi (baik di dalam organisasi dandengan organisasi lain), pembelian asuransi, memperoleh informasi tentang produk danlayanan, sesuai dengan kontrak dan banyak lagi. Biaya dari semua ini berpotensi dapatdikurangi dengan sistem TI yang lebih baik. Hal ini terutama berlaku dengan jaringan,yang dapat mengurangi biaya komunikasi antara bagian geografis terpisah dari organisasi, pemasok dan pelanggan.

Hal positif yang dapat diperoleh dengan memanfaatkan jaringan internet dalam mengembangkan usaha adalah :

(1) dapat mempertinggi promosi produk dan layanan melalui kontak langsung, kaya informasi, dan interaktif dengan pelanggan,

(2) menciptakan satu saluran distribusi bagi produk yang ada,

(3) biaya pengiriman informasi ke pelanggan lebih hemat jika dibandingkan dengan paket atau jasa pos,

(4) waktu yang dibutuhkan untuk menerima atau mengirim informasi sangat singkat, hanya dalam hitungan menit atau bahkan detik.

Oleh karena itu, agar UMKM di Kota Kediri dengan segala keterbatasannya dapat berkembang dengan memanfaatkan teknologi informasi, perlu dukungan berupa pelatihan dan penyediaan fasilitas. Tentu saja tanggungjawab terbesar untuk memberi pelatihan dan penyediaan fasilitas ini ada di tangan Pemerintah Daerah, disamping pihak-pihak lain yang punya komitmen, khususnya kalangan perguruan tinggi. Pusat Pengembangan UMKM berbasis IT ini perlu dibangun di setiap kota atau jika mungkin di setiap kecamatan. Fasilitas tersebut berupa ruangan khusus dilengkapi dengan seperangkat komputer yang terkoneksi dengan internet, serta dilengkapi website UMKM masing-masing daerah, di bawah pengelolaan dan pembiayaan pemerintah daerah.

Mengapa perlu dibuat Pusat Pengembangan UMKM Berbasis IT di tingkat kota atau kecamatan? Hal ini didasari pada kenyataan bahwa sebagian besar. UMKM berlokasi di desa-desa dan kota-kota kecamatan, serta belum mampu untukmemiliki jaringan internet sendiri, apalagi memiliki websitenya. Padahal untukpengembangan usaha dengan akses pasar global harus memanfaatkan media virtual.Pusat Pengembangan UMKM Berbasis IT ini akan memudahkan UMKM dalammemperluas pasar baik di dalam negeri maupun pasar luar negeri dengan waktu danbiaya yang efisien. Sehingga tingkat kesejahteraan masyarakat UMKM dan tenaga kerja yang terlibat di dalamnya akan meningkat, dan secara bersinergi akan berdampak positif terhadap keberhasilan pembangunan nasional.

Pada dasarnya produk UKM Indonesia banyak memiliki kualitas sama dengan produk luar negeri, atau bahkan lebih baik lagi. Namun produk luar tersebut seringkali unggul dalam teknologi, baik dalam teknologi produksi, pengemasan maupun pemasarannya.

Guna memenangkan persaingan, UMKM juga harus berkembang sesuai dengan perkembangan jaman. Pada dasarnya dengan bantuan Teknologi Informasi dan Komunikasi dapat meningkatkan kinerja sehingga lebih efektif dan efisien. Jadi meskipun ada sedikit perbedaan cost dengan sistem tradisional, UMKM dapat menikmati fasilitas dari IT yang akan memberikan return yang 
sepadan. Dengan IT UMKM akan lebih siap untuk bersaing tidak hanya di dalam negeri tetapi juga dengan produk-produk luar negeri. Kita dapat bersaing dari segi kualitas, pengemasan, dan kecepatan operasi perusahaan serta yang lebih penting lagi adalah dalam pemasaran produk UMKM.

\subsection{Membangun Daya Saing}

Disamping menghadapi era globalisasi, tantangan yang sedang dihadapi pemerintah daerah Kota Kediri adalah demokratisasi dan desentralisasi atau otonomisasi. Demokratisasi dicirikan oleh kebebasan berfikir, berkata, dan bertindak. Demikian juga dalam era otonomisasi dimana peran pemerintah pusat tidak seperti pada era sebelumnya yang sentralistis. Masing-masing daerah bebas mengembangkan kreasi sesuai dengan kebutuhan dan kemampuannya. Oleh karenanya beberapa hal yang menjadi poin penting guna mampu membangun daya saing daerah, yaitu (1) harus selalu kreatif, inovatif, dan mampu memahami perubahan yang terjadi; (2) mampu menggali dan mengembangkan sumberdaya lokal yang memiliki keunggulan yang komparatif menjadi keunggulan kompetitif, (3) adanya komitmen bersama untuk mengembangkan pengrajin baru yang memiliki semangat dan jiwa kewirausahaan yang tinggi.

\section{F. KESIMPULAN DAN REKOMENDASI}

Berdasarkan tujuan penelitian, hipotesis dan analisis, maka dapat ditarik kesimpulan dan saran sebagai berikut :

\subsection{Kesimpulan}

1. Dilihat dari beberapa pendekatan diatas, maka dapat disimpulkan bahwa dalam strategi pemberdayaan UMKM menggunakan pendekatan yang terakhir. Peran Pemerintah dalam hal ini sebagaimana pendapat Cornelis dan Miar (2005:84), adalah untuk memfasilitasi dan memberdayakan para pelaku UMKM yang belum berdaya menuju ke tingkat lebih berdaya, dan yang sudah berdaya dikembangkan kearah yang lebih maju serta diharapkan mampu mengangkat para pengusaha yang belum berdaya tersebut dan tentunya harus ada peran aktif serta partisipasi masyarakat didalamnya serta dapat memberikan hasil yang lebih baik.

2. Strategi untuk mengembangkan Usaha Mikro, Kecil, dan Menengah (UMKM) di Kota Kediri tidak terlepas dari dukungan perbankan dalam penyaluran kredit. Saat ini skim kredit yang sangat familiar di masyarakat adalah Kredit Usaha Rakyat (KUR), yang khusus diperuntukkan bagi UMKM dengan kategori usaha layak, tanpa agunan. Selain itu penguatan lembaga pendamping UMKM dapat dilakukan melalui kemudahan akses serta peningkatan capacity building dalam bentuk pelatihan dan kegiatan penelitian yang menunjang pemberian kredit kepada UMKM.

3. Strategi untuk mengantisipasi mekanisme pasar yang makin terbuka dan kompetitif khususnya di kawasan Asean adalah penguasaan pasar, yang merupakan prasyarat untuk meningkatkan daya saing UMKM. Agar dapat menguasai pasar, maka UMKM perlu mendapatkan informasi dengan mudah dan cepat, baik informasi mengenai pasar produksi maupun pasar faktor produksi untuk memperluas jaringan pemasaran produk yang dihasilkan oleh UMKM. Aplikasi teknologi informasi pada usaha mikro, kecil dan menengah akan mempermudah UMKM dalam memperluas pasar baik di dalam negeri maupun pasar luar negeri dengan efisien. Pembentukan Pusat Pengembangan UMKM berbasis IT dianggap mampu mendorong pertumbuhan dan perkembangan usaha mikro, kecil, dan menengah di era teknologi informasi saat ini.

\subsection{Rekomendasi}

Guna mengupayakan pengembangan usaha kecil rumah tangga UMKM yaitu di Kota Kediri maka disarankan :

1. Untuk meningkatkan daya saing diperlukan sinergi antara peran pemerintah selakupembuat kebijakan serta lembaga pendamping, khususnya lembaga keuangan mikrountuk mempermudah akses 
perkreditan dan perluasan jaringan informasi pemasaran. Selain itu, budaya mencintai produksi dalam negeri juga perlu dipupuk agar UMKM berkembang dan perekonomian nasional menjadi lebih kuat.

2. Pelaku usaha mikro, kecil dan menengah perlu aktif untuk bekerjasama dan berkoordinasi dengan Pemerintah maupun Pemerintah Daerah untuk terus melakukan pembinaan dan pelatihan secara kontinyu dan berkesinambungan melalui peningkatan capacity building dan penerapan aplikasi information technology (IT), termasuk mengefektifkan kembali web Pemda-Pemda saat ini yang tidak optimal sebagai basis komunikasi UMKM di daerah.

3. Membentuk Usaha Kelompok Bersama (UKB), diharapkan kedudukan usaha rumah tangga petani di desa Puhjajar akan menjadi kuaat dan mudah dalam memperoleh bahan baku, akses terhadap modal, mampu dalam menghadapi persaingan serta memasarkan produk.

4. Rencana rencanastrategi ini diharapkan mampu memberikan arahan, dorongan dalam melaksanakan kegiatan operasional bagi setiap pelaksanaan kegiatan Dinas Koperasi UMKM Kota Kediri untuk menumbuhkan kesatuan gerak dan langkah seluruh komponen organisasi dalam melaksanakan visi dan misi yang telah ditetapkan Dengan demikian untuk keberhasilan pencapaian visi dan misi Dinas Koperasi UMKM Kota Kediri yang telah ditetapkan, maka seluruh personil dari setiap level dituntut untuk bekerja keras serta berbenah diri, untuk :

- Menumbuhkan kepedulian yang tinggi terhadap organisasi secara keseluruhan, tidak hanya puas dengan menyelesaikan tugas pokok dan fungsinya secara baik, tetapi lebih dari itu perlu memberikan kontribusi serta memiliki pandangan yang lebih luas dan jernih tentang berbagai aspek keberhasilan organisasi.

- Meningkatkan kemampuan personil, koordinasi dan kerjasama dalam mewujudkan hasil kerja yang lebih maksimal

- Bekerja secara proaktif, didasari penelaahan secara mendalam dalam upaya menghindari kesalahan dan kekeliruan dalam menjalankan kegiatan berorganisasi.

- $\quad$ Mengikuti dan mencermati berbagai peristiwa aktual, kemudian melakukan analisis secara mendalam untuk mempersiapkan langkah-langkah ke depan.

- Menyatukan segala potensi yang ada dari berbagai disiplin ilmu untuk secara bersama-sama menyelesaikan bidang tugas organisasi.

\section{F. REFERENSI}

Arsyad, L, 2007, Petani Desa dan Kemiskinan. BPFE, Yogyakarta

Badan Pengembangan Indistri Kecil, 2004, Program Lima Tahun Pengembangan

Industri Kecil dan Menengah pada PELITA VI

Bank Indonesia. 2011. Five Finger Philosophy:Upaya Memberdayakan UMKM,

(online),(http://www.bi.go.id/web/id/UM KMBI/Koordinasi/Filosofi+Lima+Jari /,diakses 3 oktober 2011)

Certo, Samuel \& Peter, Paul, 2000, Strategi Managemen. Mc Graw Hill,

New York.

Diskop Jatim. 2010. Sinkronisasi Pembangungan KUMKM. (online),

(http://lensa.diskopjatim.go.id/liputankhusus/23-liputan-khusus/175sinkronisasipembangunankumkm.html, diakses 10 oktober 2011)

Drucker, Peter F, 2002, Managing for the Future. Truman Talley Books,

New York 
Ermawati, E, 2004, Subkontrak dan Implikasinya Terhadap Pekerja Perempuan.

Akatiga, Bandung

Fred, David, 2005, Concept of Strategi Management. Macmilan Publishing Co,

New York

Galeri UKM. 2011. Kriteria Usaha Mikro Kecil dan Menengah, (Online),

(http://galeriukm.web.id/news/kriteriausaha-mikro-kecil-dan-menengahumkm,diakses 1 oktober 2011)

Harsono, 2010, Manajemen Pabrik. Balai Aksara, Jakarta

Hidayat, Hamid, 2011, Masalah Struktur Agraria dan Kedudukan Sosial Ekonomi

Masyarakat di Desa Pujon. Thesis IPB, Bogor

Kotler, P, 2010, Manajemen Pemasaran Analisa, Perencanaan dan Pengendalian.

Erlangga, Jakarta

Kuncoro, M, 2007, Ekonomi Pembangunan. AMP YKPN, Yogyakarta

Kusnadi, M, 2011, Penggunaan Sumber Daya dan Partisipasi Masyarakat

Terhadap Lembaga Pelayanan di Pedesaan DAS Kunto. Thesis IPB, Bogor

Sabirin, S. 2001. Pemanfaatan Kredit Mikro untuk Mendorong Pertumbuhan Ekonomi Rakyat di dalam Era Otonomi Daerah. Orasi Ilmiah Lustrum IX Universitas Andalas, Padang, 13 September2001.

Setyobudi, Andang. 2007. Peran serta Bank Indonesia dalam Pengembangan Usaha Mikro, Kecil, dan Menengah (UMKM), Buletin Hukum Perbankan dan Kebanksentralan, Volume 5, nomor 2, Agustus 2007. Jakarta: Bank Indonesia.
Sudaryanto dan Hanim,Anifatul. 2002. Evaluasi kesiapan UKM Menyongsong Pasar Bebas Asean(AFTA) : Analisis Perspektif dan Tinjauan Teoritis. Jurnal Ekonomi Akuntansi dan Manajemen, Vol 1 No 2, Desember 2002

Sugiyono, 2012, Metode Penelitian Kuantitatif, Kualitatif Dan R \& D, Bandung : Alfabeta.

Suwarsono, 2004, Management Strategik, Pengantar Proses Berfikir Strategik.

Bina Aksara, Jakarta

Suyanto, M. 2005. Artikel, Aplikasi IT untuk UKM Menghadapi Persaingan Global. Yogyakarta

Umar, Husen, 2009, Riset Strategi Perusahaan. Pt. Gramedia Pustaka, Jakarta

Vredenberg, J, 1984, Metode dan Teknik Penelitian Masyarakat, Jakarta : PT Gramedia

Undang-undangRepublik Indonesia Nomor 25 Tahun 2009 tentang Pelayanan Publik

Undang-undang Republik Indonesia Nomor 20 Tahun 2008 tentang Usaha Mikro, Kecil, Dan Menengah

Undang-undang Nomor 25 Tahun 1992 tentang Perkoperasian (Lembaga Negara Tahun 1992 Nomor 116, Tambahan Lembaran Negara Nomor 3611)

Peraturan Pemerintah Nomor 32 Tahun 1998 tentang Pembinaan dan pengembangan Usaha Kecil

Peraturan Pemerintah Nomor 79 Tahun 2005 tentang Pedoman Pembinaan dan Pengawasan Penyelenggaraan Pemerintah Daerah

Peraturan Daerah Kota Kediri Nomor 1 Tahun 2007 tentang Anggaran Pendapatan dan Belanja Daerah Tahun Anggaran 2007 
Peraturan Daerah Kota Kediri Nomor 19 Tahun 2007 Tentang Modal Penyertaan Melalui Program Pemberdayaan Kepada Koperasi, Usaha Mikro, Kecin Dan Menengah

Peraturan Daerah Kota Kediri Nomor 6 Tahun 2008 tentang Struktur Organisasi Tata Kerja Lembaga Teknis Daerah;
Peraturan Walikota Kediri Nomor 51 Tahun 2013 tentang Perubahan atas Peraturan Walikota Kediri Nomor 72 Tahun 2008 tentang uraian Tugas Pokok dan Fungsi dan Tata Kerja Dinas Koperasi, Usaha Mikro, Kecil dan Menengah Kota Kediri.

Soekanto, Sarjono. 1983. Teori Sosiologi Tentang Interaksi Sosial. Jakarta: Gahlia. 